\title{
PENGARUH KEPEMIMPINAN DAN BUDAYA ORGANISASI TERHADAP KOMPETENSI GURU SMP SULTAN AGUNG PEMATANGSIANTAR DENGAN MOTIVASI SEBAGAI MODERATING VARIABEL
}

\author{
Oleh \\ Julyanthry \\ Dosen STIE Sultan Agung Pematangsiantar
}

\section{ABSTRAKSI}

Penelitian ini bertujuan untuk menguji pengaruh kepemimpinan, budaya organisasi, dan motivasi terhadap kompetensi guru baik secara parsial maupun simultan.

Hasil dari pengujian yang dilakukan dengan SPSS diperoleh persamaan regresi berganda : $\mathbf{Y}=\mathbf{2 , 7 7 3}+$ $\mathbf{0 , 1 5 5} \mathbf{X}_{\mathbf{1}}+\mathbf{0 , 8 1 0} \mathbf{X}_{2}$. Hasil hipotesa uji t hitung variabel penelitian adalah menolak H0 dan menerima Ha, artinya secara parsial kepemimpinan dan budaya organisasi berpengaruh signifikan terhadap kompetensi guru SMP Sultan Agung Pematangsiantar

Hasil dari pengujian yang dilakukan dengan moderating diperoleh persamaan regresi berganda : $\mathrm{Y}=$ $63,419+0,850 \mathrm{ZX}_{1}+3,638 \mathrm{ZX}_{2}+2,252 \mathrm{ZX}{ }_{3}+0,046 \mathrm{AbsX}_{1}-\mathrm{X}_{3}+0,110 \mathrm{AbsX}_{2}-\mathrm{X}_{3}$. Uji hipotesis menunjukkan bahwa kelima variabel berpengaruh positif terhadap kompetensi guru. Hasil lain dapat disimpulkan bahwa variabel motivasi bukan merupakan variabel moderasi. Variabel motivasi merupakan variabel independen dalam hubungannya dengan kompetensi guru

Kata Kunci : Kepemimpinan, Budaya Organisasi, Motivasi, Kompetensi Guru dan Moderating

\section{ABSTRACT}

The objective of this research was to test the influence of leadership, organization culture, and motivation toward the teacher competences in a partial and simultaneous way.

The result of the test were performed by the SPSS obtained the multiple regression equation: $Y=2,773$ $+0,155 X_{1}+0,810 X_{2}$.

The result of the hypothesis testing $t_{\text {hitung }}$ study variable is rejecting $\mathrm{HO}$ and accepting $\mathrm{Ha}$, it means, partially variable leadership and organization culture significant influent on teacher competences on Sultan Agung Private Junior High School Pematangsiantar.

The result of the test were performed by moderating obtained the multiple regression equation : $Y=$ $63,419+0,850 \mathrm{ZX}_{1}+3,638 \mathrm{ZX}_{2}+2,252 \mathrm{ZX} \mathrm{X}_{3}+0,046 \mathrm{Abs} \mathrm{X}_{-} \mathrm{X}_{3}+0,110 \mathrm{Abs} \mathrm{X}_{2} \mathrm{X}_{3}$, The hypotesis which shows that all five variables give positive influent on teacher's competence. The another result of this research shows that motivation is not moderating variable. Motivation variable is an independent variable in relation to teacher's competence

Keywords : Leadership, Organization Culture, Motivation, Teacher Competences and Moderating

\section{A. PENDAHULUAN}

\section{Latar Belakang Masalah}

Salah satu masalah krusial yang dihadapi bangsa ini adalah rendahnya mutu pendidikan, yang bermuara pada lemahnya daya saing Sumber Daya Manusia (SDM) dan rendahnya produktifitas manusia Indonesia pada umumnya. Untuk merekayasa Sumber Daya Manusia berkualitas, yang mampu bersanding bahkan bersaing dengan negara maju, diperlukan guru dan tenaga kependidikan profesional yang merupakan penentu utama keberhasilan pendidikan Kompetensi guru di sekolah mempunyai peran penting dalam pencapaian tujuan sekolah. Kualitas dan kompetensi yang dihasilkan suatu lembaga pendidikan ditentukan beberapa faktor, salah satu di antaranya adalah kepemimpinan Kepala Sekolah.

Faktor lain yang dapat mempengaruhi kompetensi guru adalah budaya organisasi. Budaya organisasi merupakan nilai-nilai dominan yang diterapkan dan dipatuhi serta dijalankan dalam suatu organisasi yang bertujuan sebagai kunci keberhasilan organisasi dalam mencapai tujuannya. Selain itu, faktor lain yang dapat mempengaruhi kompetensi guru adalah motivasi. Motivasi merupakan cara mengerahkan dan mendorong seseorang untuk melakukan suatu kegiatan secara produktif sehingga keinginannya dan tujuan organisasi dapat sekaligus tercapai.

\section{Rumusan Masalah}

Bagaimana hubungan keempat variabel tersebut menjadi pusat perhatian dalam pembahasan penelitian ini, maka masalah dalam penelitian ini dirumuskan sebagai berikut :

a. Apakah kepemimpinan Kepala Sekolah dan budaya organisasi berpengaruh positif dan signifikan baik secara parsial maupun simultan terhadap kompetensi guru SMP Swasta Sultan Agung Pematangsiantar?

b. Apakah motivasi memoderisasi hubungan antara kepemimpinan Kepala Sekolah dan 
budaya organisasi terhadap kompetensi guru SMP Swasta Sultan Agung Pematangsiantar?

\section{Tujuan Penelitian} berikut :

Adapun tujuan penelitian ini adalah sebagai

a. Untuk mengetahui pengaruh kepemimpinan Kepala Sekolah terhadap Kompetensi guru di SMP Swasta Sultan Agung Pematangsiantar.

b. Untuk mengetahui pengaruh budaya organisasi terhadap kompetensi guru di SMP Swasta Sultan Agung Pematangsiantar.

c. Untuk mengetahui moderisasi motivasi antara kepemimpinan Kepala Sekolah dan kompetensi guru SMP Swasta Sultan Agung Pematangsiantar.

d. Untuk mengetahui moderisasi motivasi antara budaya organisasi dan kompetensi guru SMP Swasta Sultan Agung Pematangsiantar.

\section{Metodologi Penelitian}

Dalam penelitian ini, penulis menggunakan jenis penelitian eksplanatori yang menjelaskan hubungan kausal antar variabel melalui pengujian hipotesis, yakni menjelaskan pengaruh variabel bebas terhadap variabel tidak bebas, yaitu kompetensi guru (Y). Untuk melakukan penelitian dan pengumpulan data, penulis menggunakan metode dan instrumen penelitian adalah metode wawancara, metode kuisioner, metode dokumentasi.

\section{B. LANDASAN TEORI}

\section{Kepemimpinan dan Kepemimpinan Kepala Sekolah}

Menurut Handoko (2003 : 294),

kepemimpinan merupakan kemampuan yang dipunyai seseorang untuk mempengaruhi orang lain agar bekerja mencapai tujuan dan sasaran. Robbins (2002 : 163) yang mendifenisikan kepemimpinan suatu kemampuan untuk mempengaruhi sebuah kelompok untuk mencapai suatu visi atau serangkaian tujuan tertentu.

Wahjosumidjo (2002 : 83) mengartikan bahwa, Kepala Sekolah adalah seorang tenaga fungsional guru yang diberi tugas untuk memimpin suatu sekolah dimana diselenggarakan proses belajar mengajar atau tempat dimana terjadi interaksi antara guru yang memberi pelajaran dan murid yang menerima pelajaran. Berkaitan dengan kepemimpinan Kepala Sekolah Rusyan (2000) menyatakan bahwa "Kepemimpinan Kepala Sekolah memberikan motivasi kerja bagi peningkatan produktivitas kerja guru dan hasil belajar siswa.

Dalam perspektif Kebijakan Pendidikan Nasional (Depdiknas, 2006), terdapat tujuh peran utama Kepala Sekolah yaitu sebagai :

a. Kepala Sekolah sebagai edukator (pendidik)

b. Kepala Sekolah sebagai manajer

c. Kepala Sekolah sebagai administrator

d. Kepala Sekolah sebagai supervisor (penyelia)

e. Kepala Sekolah sebagai leader (pemimpin)

f. Kepala Sekolah sebagai pencipta iklim kerja

g. Kepala Sekolah sebagai wirausahawan

\section{Budaya Organisasi}

Menurut Sutrisno (2010 : 2), budaya organisasi merupakan perangkat sistem nilai-nilai (values), keyakinan-keyakinan (beliefs), asumsiasumsi (assumptions) atau norma-norma yang telah berlaku, disepakati, dan diikuti oleh para anggota organisasi sebagai pedoman perilaku dan pemecahan masalah organisasi. Luthans (2006) memberikan gambaran berkenaan dengan karakteristik penting dari budaya organisasi, yaitu :

a. Aturan-aturan perilaku, yang dapat dijadikan pedoman dalam hubungan antara anggota organisasi, komunikasi, terminologi, dan upacara-upacara (ritual).

b. Norma-norma, berupa aturan-aturan tak tertulis yang menentukan bagaimana cara bekerja.

c. Nilai-nilai dominan, mengandung konsepsi yang jelas atau keyakinan tentang hal-hal yang diinginkan atau diharapkan oleh anggota organisasi, seperti konsepsi nilai tentang kualitas, efisiensi tinggi, absensi rendah dan sebagainya.

d. Filosofi, berkaitan dengan kebijaksanaan organisasi menyangkut cara memperlakukan anggota organisasi dan pihak-pihak yang berkepentingan

e. Peraturan-peraturan, yang berisi petunjuk tentang pelaksanaan tugas-tugas dalam organisasi.

f. Iklim organisasi, yang menggambarkan lingkungan fisik organisasi, perilaku hubungan antara anggota, juga hubungan organisasi dengan pihak-pihak luar organisasi.

\section{Motivasi}

Motivasi membahas bagaimana caranya mengarahkan daya dan potensi bawahan agar mau bekerjasama secara produktif berhasil mencapai dan mewujudkan tujuan yang telah ditetapkan (Hasibuan, dalam Sutrisno, 2009 : 110). Menurut Mulyasa (2003 : 112) motivasi adalah tenaga pendorong atau penarik yang menyebabkan adanya tingkah laku ke arah suatu tujuan tertentu.

McClelland dan kawan-kawan mengajukan tiga motif atau kebutuhan utama di tempat kerja, yaitu:

1) Kebutuhan akan pencapaian (Need for Achievement) merupakan daya penggerak yang memotivasi semangat kerja seseorang untuk berkreativitas dan berprestasi, sehingga dengan prestasi ini ia akan memperoleh pendapatan yang besar.

2) Kebutuhan akan hubungan (Need for Affiliation) merupakan daya penggerak yang memotivasi semangat kerja seseorang karena ia diterima orang lain, dihormati, kebutuhan untuk maju dan kebutuhan berpartisipasi.

3) Kebutuhan akan kekuasaan (Need for Power) merupakan daya penggerak yang memotivasi semangat kerja seseorang untuk mencapai kekuasaan atau kedudukan yang terbaik. 


\section{Kompetensi Guru}

Menurut Syamsudin (Agung, 2014 : 35), kompetensi guru merupakan seperangkat pengetahuan, keterampilan dan perilaku yang harus dimiliki, dihayati, dikuasai, dan diaktualisasikan oleh guru dalam melaksanakan tugas utamanya. Dalam Undang-undang Guru dan Dosen No. 14 Tahun 2005 mengamanatkan bahwa guru sebagai tenaga profesional harus memiliki kompetensi yang memenuhi standar (teruji dan bersertifikat). Berkenaan dengan implementasi Undang-undang tersebut, Departemen Pendidikan Nasional sejak tahun 2007 telah melakukan ujian sertifikasi bagi para guru secara bertahap, diharapkan dalam kurun waktu 10 tahun ke depan semua guru sudah mendapat sertifikasi kompetensi.

Undang-Undang RI Nomor 14 tahun 2005 tentang Guru dan Dosen Pasal 8 menyatakan Guru wajib memiliki kualifikasi akademik, kompetensi, sertifikat pendidik, sehat jasmani dan rohani, serta memiliki kemampuan untuk mewujudkan tujuan pendidikan nasional. Kualifikasi akademik diperoleh sebagaimana dimaksud dalam pasal 8 diperoleh melalui pendidikan tinggi program sarjana atau program diploma empat. Kompetensi guru sebagaimana dimaksud dalam pasal 8 meliputi kompetensi pedagogik, kompetensi kepribadian, kompetensi sosial, dan kompetensi profesional yang diperoleh melalui pendidikan profesi.

\section{PEMBAHASAN}

\section{Analisa}

\section{a. Deskriptif Kualitatif}

Guru-guru SMP Swasta Sultan Agung Pematangsiantar memiliki usia yang bervariasi. Usia guru-guru SMP Swasta Sultan Agung kebanyakan diatas 40 tahun. Secara fisik dan psikologis faktor usia merupakan salah satu faktor yang mempengaruhi cara bekerja seseorang. Secara fisik dan psikologis faktor jenis kelamin juga merupakan salah satu faktor yang memepngaruhi cara bekerja seseorang. Mayoritas SMP Swasta Sultan Agung memiliki jumlah guru perempuan yang lebih banyak $(60,6 \%)$ dibandingkan dengan laki-laki $(39,4 \%)$.

Mayoritas pendidikan terakhir Guru SMP Swasta Sultan Agung Pematangsiantar adalah Sarjana S-1 sebanyak 75,8\% disusul dengan tingkat pendidikan Pasca Sarjana ( S-2) 12,1\% kemudian tingkat Diploma 9,1\% dan SMA 3,0\%. Jumlah responden berdasarkan status kepegawaian menunjukkan bahwa guru tetap adalah yang paling banyak atau 54,5\% dan diikuti guru tidak tetap yayasan $45,5 \%$

\section{b. Deskriptif Kuantitatif}

\section{1) Analisis Regresi Berganda}

Teknik analisa data yang digunakan dalam penelitian ini adalah analisa statistik regresi linier berganda dengan menggunakan program SPSS 17. Analisis regresi digunakan untuk memprediksi pengaruh variabel bebas terhadap variabel terikat.

Teknik analisa statistik regresi linear berganda dengan menggunakan program SPSS 17. Hasil analisa regresi berganda digunakan untuk melihat pengaruh dari variabel independet/bebas terhadap variabel dependent/terikat dengan hasil analisa dengan program SPSS pada tabel di atas dapat dilihat model regresi yang dihasilkan sebagai berikut $: \mathrm{Y}=\mathbf{2 , 7 7 3}+\mathbf{0 , 1 5 5} \mathrm{X}_{\mathbf{1}}+\mathbf{0 , 8 1 0} \mathrm{X}_{2}$

Dari model persamaan regresi berganda yang diperoleh di atas dapat diartikan bahwa variabel bebas yakni kepemimpinan dan budaya organisasi menunjukkan hubungan yang searah atau positif terhadap kompetensi guru

a) Koefesien Korelasi dan Koerfesien Determinasi

Untuk melihat seberapa besar variasi kompetensi professional guru dapat dijelaskan oleh variasi kepemimpinan dan budaya organisasi dapat diketahui dari perhitungan Koefisien Determinasi $\left(\mathrm{R}^{2}\right)$. Perhitungan koefisien determinasi menunjukkan bahwa nilai $\mathrm{R}$ Square yang cukup tinggi. Yang berarti variasi kepemimpinan dan budaya organisasi dapat menjelaskan variasi dari kompetensi professional guru SMP Swasta Sultan Agung Pematangsiantar sebesar $.877(87,7 \%)$ dan sisanya sebesar $12,3 \%$ dapat dijelaskan oleh faktor lain yang tidak dibahas dalam penelitian ini, seperti pelatihan, komitmen organisasi, komunikasi dan faktor lainnya.

Tabel 2

Tabel Koefisien Determinasi Model Summary ${ }^{\mathrm{b}}$

\begin{tabular}{|c|r|r|r|r|}
\hline Model & $\mathrm{R}$ & R Square & $\begin{array}{l}\text { Adjusted R } \\
\text { Square }\end{array}$ & $\begin{array}{l}\text { Std. Error of } \\
\text { the Estimate }\end{array}$ \\
\hline 1 & $.936^{\mathrm{a}}$ & .877 & .869 & 2.29070 \\
\hline
\end{tabular}

a. Predictors: (Constant), BUDAYA, KEPEMIMPINAN

b. Dependent Variable: KOMPETENSI

Sumber : Data Primer diolah 2015,SPSS

b) Pengujian Hipotesa

Uji t pada dasarnya menunjukkan seberapa jauh pengaruh variabel bebas secara individual dalam menerangkan variasi variabel terikat. Untuk menguji hasil perhitungan regresi dapat dilakukan pembuktian hipotesa untuk mengetahui apakah variabel bebas mempunyai pengaruh yang signifikan atau tidak terhadap variabel terikat secara Parsial.

Dengan penggunaan program SPSS 17 pada Tabel 1 di atas, maka hasil uji t pada penelitian bahwa :

a. Hasil pengujian variabel kepemimpinan diperoleh $t_{\text {hitung }}$ 2,229 dengan probabilitas signifikan 0,033 lebih kecil dari tingkat keyakinan (level of significant) $\alpha=0,05$. Maka keputusan yang diambil adalah menolak Ho dan menerima Ha. Artinya secara parsial kepemimpinan berpengaruh positif dan signifikan terhadap kompeternsi guru SMP Sultan Agung Pematangsiantar.

b. Hasil pengujian variabel budaya organisasi diperoleh $\mathrm{t}_{\text {hitung }} 12,310$ dengan probabilitas signifikan 0,000 lebih kecil dari tingkat

\begin{tabular}{lllll}
\hline Jurnal SULTANIST & ISSN : 2338-4328 & Vol. 4, No. 1, & JUNI 2016 & 25
\end{tabular}


keyakinan (level of significant) $\alpha=0,01$. Maka keputusan yang diambil adalah menolak Ho dan menerima $\mathrm{Ha}$, artinya secara parsial budaya organisasi berpengaruh positif dan signifikan terhadap kompetensi guru SMP Swasta Sultan Agung Pematangsiantar.

c. Dari kedua variabel bebas diatas, dapat dilihat bahwa variabel budaya organisasi berpengaruh paling tinggi atau dominan $\left(\beta_{2}>\beta_{1}\right)$ terhadap kompetensi guru SMP Sultan Agung Pematangsiantar.

\section{2) Analisis Regresi Berganda dengan Moderating}

Metode yang digunakan dalam penelitian ini adalah analisis regresi variabel moderasi dengan metode selisih mutlak dilakukan dengan meregresikan selisih mutlak variabel bebas terstandarisasi dengan variabel yang dihipotesiskan sebagai variabel moderasi terstandarisasi. Dalam buku Suliyanto (2011 : 218) merumuskan model persamaan sebagai berikut:

$$
\mathrm{Y}=\mathrm{a}+\mathrm{b}_{1} \mathrm{ZX}_{1}+\mathrm{b}_{2} \mathrm{ZX}_{2}+\mathrm{b}_{3} \mathrm{ZX}_{3}+\mathrm{b}_{4} \mid \mathrm{Abs}_{1}
$$
${ }_{-} \mathrm{X}_{3}\left|+\mathrm{b}_{5}\right| \mathrm{Abs}_{2} \mathrm{X}_{3} \mid+\mathrm{e}$

Teknik analisa statistik regresi linear berganda dengan menggunakan program SPSS 17. Hasil analisa regresi berjenjang digunakan untuk melihat pengaruh dari variabel moderating terhadap variabel bebas Berdasarkan hasil uji nilai selisih mutlak diperoleh persamaan regresi sebagai berikut: $\mathrm{Y}=63,419+0,850 \mathrm{ZX}_{1}+3,638 \mathrm{ZX}_{2}+2,252 \mathrm{ZX}_{3}+$ $0,046 \mathrm{Abs}_{1} \mathrm{X}_{3}+0,110 \mathrm{AbsX}_{2}-\mathrm{X}_{3}+\mathrm{e}$

Dari hasil SPSS ditunjukkan bahwa variabel ZKepemimpinan memberikan nilai koefisien 0,850 dengan probabilitas signifikan 0,053. Dari data tabel di atas dapat disimpulkan bahwa pada taraf signifikansi $5 \%$, diketahui kepemimpinanan berpengaruh positif, tapi tidak signifikan terhadap kompetensi professional guru. Tetapi apabila tingkat signifikansi dinaikkan menjadi $10 \%$ maka kepemimpinan akan berpengaruh positif dan signifikan terhadap kompetensi guru. Yang artinya, pada taraf signifikansi $10 \%$, motivasi akan memperkuat pengaruh kepemimpinan terhadap kompetensi guru. Variabel Zbudaya organisasi memberikan nilai koefisien 3,638 dengan probabilitas 0.000 menunjukkan bahwa budaya organisasi bermoderasi dengan kompetensi guru, yang artinya motivasi akan memperkuat pengaruh budaya organisasi terhadap kompetensi guru. Variabel Zmotivasi memberikan nilai koefisien 2,252 dengan probabilitas 0.007 yang artinya bahwa motivasi berpengaruh dengan kompetensi guru. Variabel moderator juga dapat dilihat bahwa Abs $\mathrm{X}_{1} \mathrm{X}_{3}, \operatorname{Abs} \mathrm{X}_{2} \mathrm{X}_{3}$, ternyata tidak signifikan yaitu dengan probabilitas signifikan jauh diatas 0,05 . Temuan ini menunjukkan bahwa variabel motivasi adalah bukan sebagai variabel moderator. Hasil ini mendukung penelitian Sulistio (2009) dan Muryanto (2011), yang menyatakan bahwa motivasi bukan sebagai variabel moderator, akan tetapi cenderung sebagai variabel independen (predictor)

\section{c) Koefesien Korelasi dan Koerfesien} Determinasi

Untuk melihat seberapa besar pengaruh variabel bebas terhadap variabel terikat dapat diketahui dari perhitungan Koefisien Determinasi $\left(\mathrm{R}^{2}\right)$ yang ditunjukkan Tabel 4.13 berikut dengan pengolahan SPSS 17 sebagai berikut :

Tabel 4

Tabel Koefisien Determinasi Moderasi Model Summary ${ }^{\mathrm{b}}$

\begin{tabular}{|c|r|l|l|l|}
\hline Model & $\mathrm{R}$ & $\begin{array}{l}\mathrm{R} \\
\text { Square }\end{array}$ & $\begin{array}{l}\text { Adjusted R } \\
\text { Square }\end{array}$ & $\begin{array}{l}\text { Std. Error of the } \\
\text { Estimate }\end{array}$ \\
\hline 1 & $.952^{\mathrm{a}}$ & .906 & .889 & 2.10755 \\
\hline a. Predictors: (Constant), ABSX2 X3, Zscore(BUDAYA),
\end{tabular}
(Constant), ABSX2_X3, Zscore(BUDAYA), Zscore(MOTIVASI)

b. Dependent Variable: KOMPETENSI

Sumber : Data Primer diolah 2015,SPSS

Tampilan output SPSS diatas menunjukkan nilai R Square sebesar cukup tinggi .906 atau 90,6\% yang berarti variasi kompetensi guru dapat dijelaskan oleh variasi Zkepemimpinan, Zbudaya organisasi, Zmotivasi dan Abs $\mathrm{X}_{1} \mathrm{X}_{3}$ Abs $\mathrm{X}_{2} \mathrm{X}_{3}$, sebesar $90,6 \%$ dan sisanya $9,4 \%$ dijelaskan oleh variabel lain diluar model ini. Jadi dapat dikatakan model sangat kuat.

\section{a) Pengujian Hipotesa (Uji F)}

Untuk melihat apakah secara bersamasama/serempak (simultan) variabel independen berpengaruh terhadap variabel dependen dapat dilihat dari perhitungan tampilan output SPSS Uji Signifikansi Simultan (Uji Statistik F).

Dengan bantuan program SPSS, hasil uji F pada penelitian ini dapat dilihat pada tabel berikut

Tabel 5

Uji F Statistik Moderas

ANOVA $^{\mathrm{b}}$

\begin{tabular}{|r|l|l|l|l|l|}
\hline Model & $\begin{array}{c}\text { Sum of } \\
\text { Squares }\end{array}$ & Df & $\begin{array}{c}\text { Mean } \\
\text { Square }\end{array}$ & F & Sig. \\
\hline Regression & 1157.043 & 5 & 231.409 & 52.09 & $.000^{\mathrm{a}}$ \\
Residual & 119.927 & 27 & 4.442 & & \\
Total & 1276.970 & 32 & & & \\
\hline a. Predictors: & (Constant), & \multicolumn{2}{|c|}{ ABSX2 X3, Zscore(BUDAYA), }
\end{tabular}

b. Dependent Variable: KOMPETENSI

Dari hasil Anova atau F test menunjukkan bahwa nilai $\mathrm{F}$ hitung sebesar 52,099 dengan tingkat signifikansi 0,000 jauh dibawah 0,05 . Hal ini berarti bahwa variabel standardized kepemimpinan, standardized budaya organisasi, standardized motivasi dan $\mathrm{ABSX}_{1} \mathrm{X}_{3}, \mathrm{ABSX}_{2} \mathrm{X}_{3}$ secara bersama-sama atau simultan mempengaruhi kompetensi guru.

\section{Evaluasi}


1) Kompetensi Guru pada SMP Swasta Sultan Agung

Kompetensi merupakan kemampuan untuk melaksanakan satu tugas, peran atau tugas, kemampuan mengintegrasikan pengetahuan, ketrampilan-ketrampilan, sikap-sikap dan nilai-nilai pribadi, dan kemampuan untuk membangun pengetahuan dan keterampilan yang didasarkan pada pengalaman dan pembelajaran yang dilakukan. Kompetensi guru merupakan kebulatan pengetahuan, keterampilan dan sikap yang berwujud tindakan cerdas dan penuh tanggung jawab dalam melaksanakan tugas sebagai agen pembelajaran.

Kompetensi guru SMP Swasta Sultan Agung dapat dilihat dari berbagai faktor seperti yang terdapat dalam pertanyaan kuesioner. Adapun hasil yang diperoleh untuk kompetensi guru adalah sebanyak $18 \%$ masih dalam tingkatan kurang baik, $38 \%$ dalam tingkatan baik, serta $44 \%$ berkategori sangat baik.

\section{2) Kepemimpinan Kepala Sekolah pada} SMP Swasta Sultan Agung

Kepemimpinan kepala sekolah adalah kemampuan kepala sekolah untuk memimpin dan mengelola segala sumber daya yang ada pada suatu sekolah sehingga dapat didayagunakan secara maksimal untuk mencapai tujuan. Kepemimpinan kepala sekolah pada SMP Swasta Sultan Agung dapat dilihat dari berbagai faktor seperti yang terdapat dalam pertanyaan kuesioner. Adapun hasil yang diperoleh untuk kepemimpinan adalah sebanyak 20\% masih dalam tingkatan cukup baik, $37 \%$ dalam tingkatan baik, serta $43 \%$ berkategori sangat baik.

\section{3) Budaya Organisasi pada SMP Swasta} Sultan Agung

Budaya organisasi merupakan nilai-nilai dominan yang diterapkan dan dipatuhi serta dijalankan dalam suatu organisasi yang bertujuan sebagai kunci keberhasilan organisasi dalam mencapai tujuannya. Budaya sekolah mendapat perhatian karena menunjukkan keunikan sosial dari suatu organisasi yang menggambarkan kepribadian sekolah tersebut dalam menjalankan peran dan tugasnya dalam mendidik masyarakat.

Budaya organisasi pada SMP Swasta Sultan Agung dapat dilihat dari berbagai faktor seperti yang terdapat dalam pertanyaan kuesioner. Adapun hasil yang diperoleh untuk budaya organisasi adalah sebanyak 19\% masih dalam tingkatan cukup baik, $39 \%$ dalam tingkatan baik, serta $42 \%$ berkategori sangat baik.

\section{4) Motivasi Guru pada SMP Swasta Sultan} Agung

Motivasi adalah cara mengerahkan dan mendorong seseorang untuk melakukan suatu kegiatan secara produktif sehingga keinginannya dan tujuan organisasi dapat sekaligus tercapai. Motivasi kerja tidak hanya bersumber dari dalam diri orang itu saja, melainkan memerlukan perpaduan baik dari diri sendiri, atasan, mapun lingkungan kerja itu sendiri.

Motivasi pada SMP Swasta Sultan Agung dapat dilihat dari berbagai faktor seperti yang terdapat dalam pertanyaan kuesioner. Adapun hasil yang diperoleh untuk motivasi adalah sebanyak $18 \%$ masih dalam tingkatan kurang tinggi, 43\% dalam tingkatan tinggi, serta $39 \%$ berkategori sangat tinggi

\section{KESIMPULAN DAN SARAN}

\section{Kesimpulan}

Dari seluruh uraian yang telah dikemukakan dalam bab sebelumnya, maka penulis menarik kesimpulan sebagai berikut:

a. Bahwa kepemimpinan dan budaya organisasi berpengaruh positif dan signifikan terhadap kompetensi guru SMP Sultan Agung Pematangsiantar. Hal ini dapat dilihat dari hasil pengujian regresi yang menunjukkan tanda positif pada persamaan sebagai berikut: $Y=\mathbf{2 , 7 7 3}+\mathbf{0 , 1 5 5} X_{1}+\mathbf{0 , 8 1 0} X_{2}$

b. Hasil analisa pada analisis regresi variabel moderasi dengan metode selisih mutlak menunjukkan tabel uji signifikansi parameter individual bahwa pada taraf signifikansi 5\%, diketahui kepemimpinanan berpengaruh positif, tapi tidak signifikan terhadap kompetensi guru. Tetapi apabila tingkat signifikansi dinaikkan menjadi 10\% maka kepemimpinan akan berpengaruh positif dan signifikan terhadap kompetensi guru. Yang artinya, pada taraf signifikansi $10 \%$, motivasi akan memperkuat pengaruh kepemimpinan terhadap kompetensi guru. Berdasarkan output cooffecient, disimpulkan pada taraf signifikansi $5 \%$, budaya organisasi berpengaruh positif dan signifikan terhadap kompetensi guru.

c. Variabel Zmotivasi memberikan nilai koefisien 2,252 dengan probabilitas 0.007 yang artinya bahwa motivasi guru berpengaruh positif dan signifikan terhadap kompetensi professional guru.

d. Pada Tabel Anova atau $\mathrm{F}$ test menunjukkan bahwa nilai $\mathrm{F}$ hitung sebesar 52,099 > dari $\mathrm{F}$ Tabel sebesar 2,572 dengan tingkat signifikansi 0,000 jauh dibawah 0,05 . Hal ini berarti bahwa variabel standardized kepemimpinan, standardized budaya organisasi, standardized motivasi dan $\mathrm{ABSX}_{1} \mathrm{X}_{3}, \mathrm{ABSX}_{2} \mathrm{X}_{3}$ secara bersama-sama atau simultan mempengaruhi kompetensi guru.

e. Selain itu, hasil analisis menunjukkan secara parsial motivasi ternyata tidak signifikan yaitu dengan probabilitas signifikan jauh diatas 0,05 . Artinya, motivasi tidak memoderasi hubungan antara kepemimpinan dan budaya organisasi terhadap kompetensi. Temuan ini menunjukkan bahwa variabel motivasi guru pada penelitian adalah bukan sebagai variabel moderator. 


\section{Saran}

Dari kesimpulan yang telah diuraikan di atas, maka peneliti memberikan saran-saran sebagai berikut:

a. Untuk pihak manajemen sekolah

1) Variabel-variabel bebas kepemimpinan dan budaya organisasi berpengaruh signifikan dan sangat kuat terhadap kompetensi professional, maka pihak sekolah perlu mempertahankan dan meningkatkan kualitas Kepemimpinan Kepala Sekolah, memelihara budaya organisasi serta meningkatkan motivasi dan mendorong para guru agar meningkatkan kompetensinya.

2) Saran penulis agar Yayasan Perguruan Sultan Agung Pematangsiantar lebih memperhatikan faktor lainya yang meningkatkan kompetensi guru SMP Sultan Agung Pematangsiantar seperti pelatihan, lingkungan kerja, komunikasi, komitmen organisasi dan faktor lainya.

b. Untuk peneliti berikutnya, sebaiknya melakukan penelitian yang berhubungan dengan kompetensi guru dengan memperhatikan faktor lain seperti komitmen organisasi, pelatihan, kepuasan kerja, dan faktor lainnya yang tidak dimasukkan dalam penelitian ini.

\section{E. DAFTAR PUSTAKA}

Handoko, Tani, 2003, Manajemen, Edisi Kedua, Yogyakarta, BPFE.

Luthan, Fred, 2006, Perilaku Organisasi, Edisi ke 10, Yogyakarta, Andi.

Mulyasa, E, 2003, Kurikulum Berbasis Kompetensi, Bandung, Remaja Rosdakarya.

Mulyasa, Edy, 2009, Menjadi Kepala Sekolah Profesional. Bandung, Remaja Rosdakarya.

Robbins, Stephen P, 2002, Prinsip-prinsip Perilaku Organisasi, Edisi Kelima, Jakarta, Erlangga.

Sutrisno, Edy, 2010, Budaya Organisasi, Jakarta, Kencana.

2009, Manajemen Sumber Daya Manusia, Edisi Revisi, Jakarta, Kencana.

Undang-Undang RI Nomor 14 tahun 2005 tentang Guru dan Dosen

Wahjosumidjo, 2002, Kepemimpinan Kepala Sekolah, Jakarta, Raja Grafindo Persada. 